\title{
STRATEGY FOR IMPLEMENTING CERTIFICATION DEVELOPMENT OF VOCATIONAL SCHOOL GRADUATES ACCORDING TO INPRES NO. 9/2016
}

\author{
Hamzah Robbani \\ Universitas Indraprasta PGRI \\ Jl. Nangka Raya No.58 Tanjung \\ Barat \\ Jakarta Selatan
}

\author{
Windi Megayanti \\ Universitas Indraprasta PGRI \\ Jl. Nangka Raya No.58 Tanjung \\ Barat \\ Jakarta Selatan
}

\author{
Nicky Rosadi \\ Universitas Indraprasta PGRI \\ Jl. Nangka Raya No.58 Tanjung \\ Barat \\ Jakarta Selatan
}

\begin{abstract}
The purpose of this study is to help determine the quality development strategy of SMK by following Presidential Instruction number 9 of 2016. This research method uses a qualitative method with a research and development approach. Data obtained using triangulation by conducting interviews with industries that are already active in absorbing direct labour from SMK graduates, then interviews from SMK management and observations at several SMK. The results of this study suggest that there are still many Vocational High Schools that have not gained awareness of Presidential Instruction No. 9/2016 so that SMKs do not know and are fully aware of the intent and purpose of the Presidential Instruction. The discussion of this study found the importance of an understanding program related to Presidential Instruction No. 9 of 2016. In addition to improving quality, junior high school students also have a better chance for graduates to get the right job.
\end{abstract}

Keywords: Quality Development, Vocational school, certification

(*) Corresponding Author: hamzahrabbani8@gmail.com dan 081282632273

\section{PRELIMINARY}

The quality of vocational education depends on 4 points, namely; 1 . Revitalization and harmonization of vocational expertise programs 2 . Adequate facilities and facilities supported by stakeholders 3. It involves the community in terms of access, and 4. It is giving special priority to expertise programs which are considered to be very supportive of the economic growth of the community. In the implementation, awareness of the world of business and the world of the industry as stakeholders who influence in developing the quality of vocational education also needs to be improved. As an effort to increase continuous improvement on both sides, the president gave his instructions through INPRES No. 9 of 2016 concerning the revitalization of SMK that SMK graduates must have competency certification in order to have competitiveness and have a bargaining position in DUDI.

Besides producing vocational graduates who can compete, school institutions are also required to improve their quality. The requirements for implementing quality learning are also by building a system that is tested and following the standards of providing vocational education. This research will observe, make comparisons, and look for the influence of what factors need to be improved by SMK institutions in producing competitive Vocational School graduates.

In the four quality points presented by Mustaghfirin Amin (2016), the first point is that the harmonization of expertise programs can be done with a synergy between 3 stakeholders; The industry is represented by the presence of companies with various classifications that are directly involved in institutions, regulations that can be represented by the sector, and the school institutions themselves as the long arm of the community. The synergy of the three is expected to be able to support the implementation of point 2 , namely adequate facilities; the intended facilities may include CSR grants from the company or sector concerned. In terms of utilizing the first and second points, of course, community commitment is needed in supporting the intended quality improvement, so the SMK schools are not only the providers of education but need to work together with the community in building mutual commitment. The last point is also one of the outputs of the synergy carried out by the first 3 point institutions. 
The guidelines for implementing education quality assurance issued by the Ministry of Education and Culture in 2016 state that quality standards and indicators cover eight things.

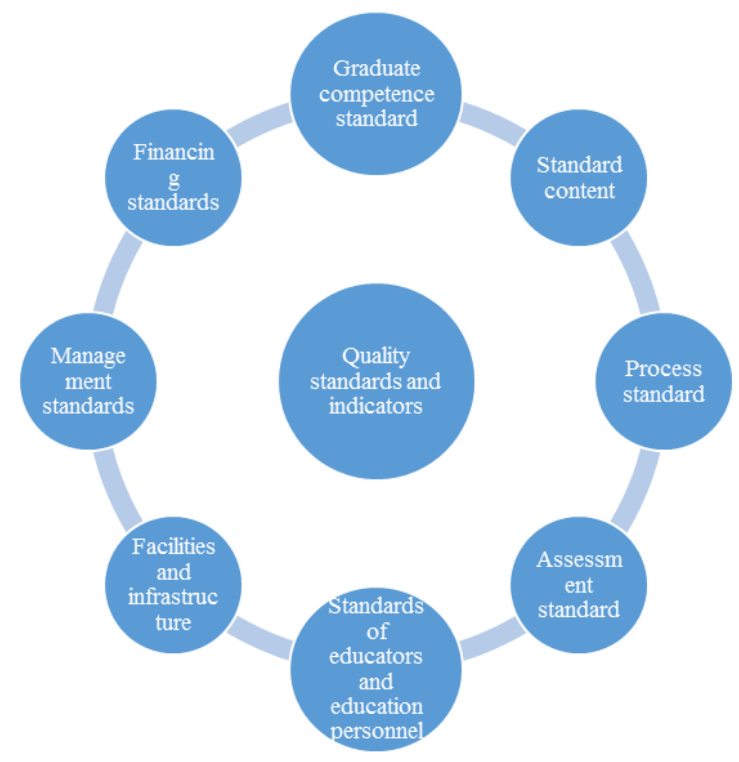

Figure 1. Quality standards and indicators

The application of quality standards above does not include the specificity of quality standards for SMK graduates who have unique characteristics, so the need for harmonization with a system that can improve the quality of SMK. Through Presidential Instruction No. 9 of 2016 concerning Vocational School Revitalization that the National Professional Certification Agency is instructed to 1. Accelerate competency certification for SMK graduates 2. Accelerate competency certification for vocational educators and teaching staff, and 3. Accelerate licensing for SMKs as firstparty professional certification bodies. In point 3 of the presidential instruction referred to the harmonization of quality improvement in terms of the system for implementing all standardized education processes according to ISO: 17024/2011. According to Herawan (2016) "Quality management implemented by schools based on ISO: 90001 has not been able to accommodate the demands of competent graduation standards, because ISO: 90001 is a management system guide that is still general in nature". BNSP (National Professional Certification Agency) has assimilated ISO: 17024/2011 into PBNSP 201, 202, 203, 206, and 210 which are easily applied in the quality management system of vocational education and other educational institutions. According to Kanjung M Advisor (2019) "there are 840 SMKs that have become LSP-P1 and have produced 125,482 professional certifications at LSP-P1 SMK".

Formulation of the problem from the background of the problem above, formulated a descriptive problem that will be explored more in the application of quality with standardized system harmonization according to INPRES No. 9 of 2016, namely; what is the strategy for implementing the development of SMK quality, especially in the graduate certification program?

This study will analyze the quality of SMK and build strategic efforts to improve its quality as described in Presidential Instruction No. 9 of 2016 concerning the revitalization of SMK, especially in the graduate certification program. SMKs that have been licensed by BNSP have independence in carrying out assessments of their students (Assrani, Mesran, Sianturi, Yuhandri, \& Iskandar, 2018). Independence in this assessment process is one of the requirements for quality development in the ISO 17024 clause regarding impartial clauses. 


\section{METHODOLOGY}

This research method uses qualitative methods with a research and development approach. Data obtained using triangulation by conducting literature studies on the Vocational Education Revitalization published by the Ministry of Education and Culture, and Presidential Decree No. $6 / 2016$, then compared with interviews. Then the researchers conducted interviews with industries that have been active in absorbing workers directly from SMK graduates, and interviews with SMK management. The research results are processed using the Cresswell method, namely 1. Processing and preparing data for analysis, 2. They are reading the entire data/processing the symptoms that occur by the object of research, 3. implementing the coding process to describe settings, people, categories and themes. To be analyzed, 4. Interpret

Supporting the statement (Robbani \& Megayanti, 2020) findings in qualitative research were obtained from the formulation to the research report. Presidential Decree no. 9/2016 is a study basis for researchers to assess the realization qualitatively. Researchers can formulate strategies as solutions for stakeholders.

\section{RESULTS AND DISCUSSION}

\section{Result}

Presidential Instruction No. 9 of 2016 is evidence of the seriousness of the government in building the quality of competitive SMK graduates. This support needs to be welcomed by SMK, one of which is by establishing LSP-P1 so that it can support graduates to have certification. Article 1 point E (in instruction two addressed to the Ministry of Education) has been explained in the Vocational Education Revitalization document issued by the Ministry of Education and Culture. In the discussion chapter 4.5, graduate competency certification explains the importance of certification because it is a requirement of work skill.

To support graduate competency certification, SMKs need to pay attention to several requirements starting from:

(1) Correct learning at school, namely making students as learning subjects who have character, competence, are independent, responsible, creative, innovative, and entrepreneurial skills;

(2) Availability of test equipment by competency standards in schools; and

(3) Certified assessors. BNSP and the Professional Association provide the Work Proficiency Certification.

In this case, the government realizes the existing gaps and has made efforts to reduce the gap by preparing a certification scheme for vocational education graduates by involving professional associations and DUDI as well as in implementing competency tests. The certification scheme compiled is based on a work competency standard (Indonesian National Work Competency Standards). Based on these competency standards, a testing and certification system is formulated.

The government's efforts did not stop at developing schemes and formulating appropriate SKKNIs. However, since 2015 Dit. For vocational training, the Ministry of Education and Culture with the National Professional Certification Agency (BNSP) has carried out activities to develop SMK into a First Party Certification Institute (LSP-P1). Some of the development activities include; 1. Facilitating the preparation and training of competency assessors; 2. Preparation of Competency Test Sites (TUK); 3. Preparation of competency test materials; 4. Training on the preparation and application of quality documents. The competency test can be carried out at LSP-P1 in each school or the nearest SMK LSP-P1.

The government has made a strategy for the formation of the LSP-P1 as follows:

1. Area approach: if in an area several SMKs do not have LSP-P1, then one LSP-P1 will be developed which can then be utilized by all SMKs in the region;

2. The formation of LSP-P1 is focused on schools with> 600 students: currently, there are about 4,000 SMK students with> 600 students, with a total number of students amounting to $90 \%$ of the total number of SMK students throughout Indonesia. 
If the LSP-P1 has met the need for certification, especially in vocational education, then the skills competency test can be replaced with a competency test conducted by the LSP-P1. The SMK Directorate plans to establish 1,650 SMKs which will act as LSP-P1 until 2019. The focus of the implementation of certification is prioritizing on 13 expertise programs (with eight expertise programs including 12 priority sectors of the AEC), namely Tourism, Catering, Beauty, Clothing, Finance, Administration, Mechanical Engineering, Automotive Engineering, Textile Technology, Chemical Engineering, Computer Engineering and Information Technology, and Telecommunication Engineering.

To support this, the Directorate of Course and Training Guidance has facilitated the formation of 35 Competency Certification Bodies (LSK) which are formed by professional organizations according to their respective fields of expertise. Each LSK determines a Competency Test Place (TUK). In preparing competency test sites, apart from being established in course and training institutions that meet the requirements to become TUK, they can also be established in other institutions, including SMK. Until 2015, there were only 1,020 course and training institutions and other institutions that had been designated as TUK. Therefore, it is necessary to strengthen course and other training institutions so that they can become TUK, and when they are accredited, they can carry out their competency tests.

Government is also planning to increase certification because, in addition to gaps in the organizing agency, there is also a gap in the workforce, including assessors and master assessors. Of the many course institutions, in Indonesia, there are only 1,460 examiners and 102 master examiners (in 2016). This causes the implementation of competency certification for Course and Training Institute students not evenly distributed, and in many areas, the frequency is infrequent. Therefore, increasing the number of examiners and master examiners is also a priority for the Directorate of Course Guidance and Training. The following is a plan to increase TUK, examiners, and master examiners by the Directorate of Course Guidance and Training.

Table 1. Plan for Increasing Student Certification

\begin{tabular}{cccccc}
\hline Year & $\mathbf{2 0 1 5}$ & $\mathbf{2 0 1 6}$ & $\mathbf{2 0 1 7}$ & $\mathbf{2 0 1 8}$ & $\mathbf{2 0 1 9}$ \\
\hline & 50 & 160 & 100 & 500 & 600 \\
Competency Test Venue & CTV & CTV & CTV & CTV & CTV \\
& 100 & 100 & 140 & 700 & 700 \\
Testers and Master Testers & People & People & People & People & People \\
Assistance to Competency & 51.733 & 65.040 & 25.000 & 25.000 & 25.000 \\
Certified Students & People & People & People & People & People \\
\hline
\end{tabular}

Source: Directorate of Course and Training, 2016

Literature study on the strategy of organizing vocational education graduate certification requires an achievement review. This can be done by triangulating so that data validity can be achieved (Hapsari 2018). The triangulation that will be carried out by researchers is by conducting interviews with stakeholders, including industry, school management, and vocational graduate students.

Thus it is hoped that researchers will obtain the validity of literature studies and can contribute to the implementation of competency certification in vocational education.

\section{Disscussion}

Interviews were conducted with real sector actors engaged in services and products.

Players in the production sector convey that our heavy equipment on-site is operated by an average high school graduate. Furthermore, we take great care in supervising the operation of our heavy equipment. Apart from that, heavy equipment such as excavators, dump trucks and other heavy equipment must be operated by a certified workforce. Companies must facilitate SMK graduates to 


\begin{abstract}
achieve these competencies and requirements. To close this gap, the company took the initiative to propose changes to the curriculum and learning model at the local SMK (the site where the production is located). Nearly half of the study period is carried out on the job training with a direct curriculum from our company so that vocational students who graduated three years can already operate heavy equipment according to their qualifications. Not only there, but we also created LSP-P1 to support prospective graduates who had been trained for three years during their vocational school years to be able to have a professional certification given by BNSP. Of course, students who get the development program from us (the company) have gone through the selection.
\end{abstract}

The development program above shows the importance of SMK graduate certification. The process of learning activities in schools is combined to meet the gap in the needs of jobs with specific qualifications. In addition, the company already has an LSP-P1 so that it can provide competency certification to prospective recruits. In addition, in the real sector in the service sector, the resource person explained the importance of graduate certification as follows.

Competency certification for SMK graduates needs to be done. This can be a kind of guarantee for us, business actors, that these human resources are indeed competent in the fields they control. Because, in practice, we were embarrassed, finding SMK graduates who did not master anything. It could be, this is what is said, passed but not competent. Because they go to school, it is just a formality. The existence of this competency certification is a filter for us to get the quality human resources that we really need.

Vocational schools such as SMKs should cooperate with Professional Certification Bodies. Why is it necessary to cooperate and not own it? Of course, to ensure the independence of the quality of the certification. The problem of graduation, let it be a school affair, is to form knowledge. Nevertheless, the matter of competence, leave it to the LSP. Because it could be, the school graduates are not in their field of expertise. Nevertheless, for those who are in this field of expertise, of course, they will pursue the quality of their competence. Human resources like this are what we need, not those who have certification.

Companies have an easy selection and placement processes when SMK graduates have professional certification. Certification is a guarantee for real sector actors. The importance of cooperation between Vocational Schools and Professional Certification Bodies is the hope of real sector actors. Because the establishment of the LSP-P1 as stated in the Vocational Education Revitalization document (2016) is still not well distributed. So the importance of strategies to make SMK graduates have a competitive edge, as explained by the two interviewees in this study. In addition to working with LSP, SMK can also collaborate with industry to build learning environments, curricula, and graduate development programs to match DUDI (Business World and industry).

The school management has a different view. In the case of SMK not having LSP-P1, the assumption is that there are several ways that can be taken. We understand very well that the Inpres emphasizes how SMK has a responsibility in producing quality graduates. Although our SMK does not yet have LSP, in essence, we are trying for industry-based learning. For example, collaboration with DUDI through street vendors, competency tests, and guest teachers. Our graduate certificate program is only at the expertise certification stage in collaboration with DUDI, DUDI, which assesses the expertise of students. It has not yet reached the competency test stage like that carried out by Professional Certification Bodies licensed by BNSP.

The school management ensures that graduate certification is maintained by implementing expertise certification in collaboration with DUDI. The results of this interview prove that the distribution of LSP-P1-based graduate certification is still unequal according to Presidential Instruction no. 9 of 2016. They were supported by the results of interviews with researchers to SMK graduates. 
At school, we have not implemented a competency certification, but we do a skills competency test. It took me quite a while to find a job. When I graduated, I did not understand where to apply for a job other than the industry I did my previous internship. Unfortunately, my internship does not need new employees. When I applied for a job, I thought it was not essential to have a competency certificate, but when I applied for a job, my colleagues had competency certificates. In addition to access to certification, SMK graduates also need training on how to submit job applications to companies.

They are supporting the opinions of the two real sector speakers who said that the solution to the gap between the lack of LSP-P1 distribution could be done by collaborating between vocational school and LSP and related industries. If the researcher summarizes it into a diagram, it can be described as follows.

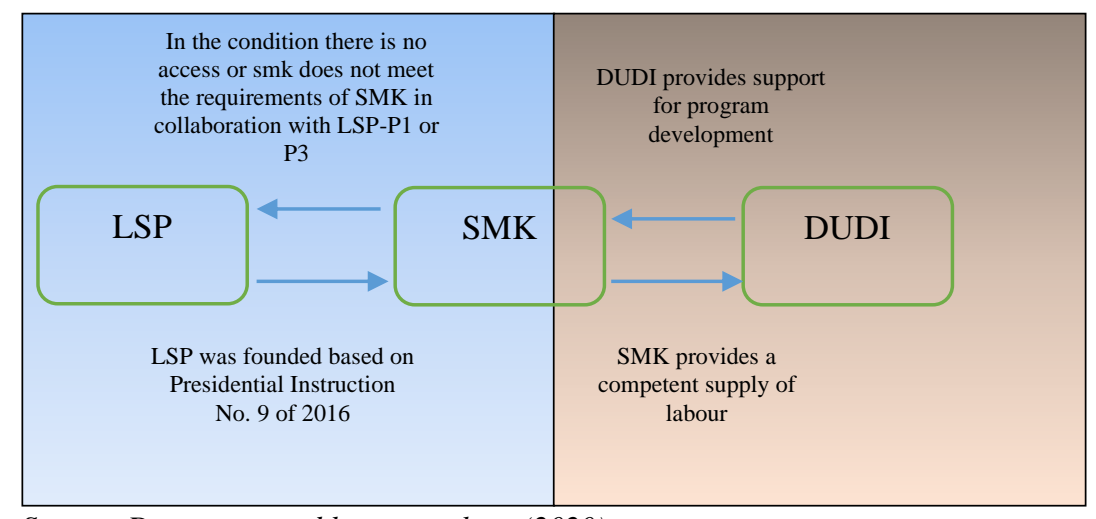

Source: Data processed by researchers (2020)

Figure 2. Strategy for SMK graduate certification

From the picture above, the researcher formulates the relationship between access to certification and the link and match area. The three stakeholders have an essential role in building the quality of highly qualified SMK graduates. This research proves the role of Professional Certification Bodies in improving the quality of SMK graduates so that they can provide job absorption according to the needs of the business and industry. Also, the business world and industry can also participate in supporting access to graduate certification by building development support programs, which include building a learning environment, curriculum, and graduate development programs.

Building a learning environment can be in the form of e-learning facilities that are combined with school programs. As explained by Robbani, Rosadi, \& Nurfitria (2020) in accordance with the Ministry of Education and Culture Circular No. 4 of 2020 learning and examinations can be done online with reference to SKKNI No. 161 units designed virtual learning environment.

In addition, the graduate certification process has also been supported by an online assessment. Several LSPs have now obtained permission after going through the witness process by BNSP to carry out online assessments. Robbani, Windi and Vendhi (2020) explain the importance of formative assessment with reliable instruments by paying attention to the side of ease of access, ease of access including friendly user interface and online applications used.

\section{CONCLUSION}

Ease of access to graduate certification is expected to be achieved with several strategies that have been described, namely:

1. SMK can cooperate with LSP-P1 or LSP-P3 if they do not have access to certification for prospective SMK graduates

2. SMK can cooperate with business and industry to build support for development programs that are not limited to; 
a. Building a competency-based curriculum according to DUDI's needs,

b. Organizing on the job training with a more intense portion, in this case, integrated with the training system at DUDI institutions,

c. Graduate certification in the form of scholarships, CSR or employee development programs for the DUDI institution.

3. School management needs to get an awareness program related to BNSP standard graduate certification.

To correct the weaknesses in this study, the researcher made the following suggestions:

1. It is necessary to evaluate the achievement of Presidential Instruction No. 9 of 2016 to all sectors contained in the Inpres.

2. Gaps in the graduate certification process need to be identified quantitatively.

3. Strategies can be developed by building a quantitative regression coefficient modelling so that the dominant factor in the graduate certification process is known.

\section{REFRENCES}

Assrani, D., Mesran, M., Sianturi, R. D., Yuhandri, Y., \& Iskandar, A. (2018). Sistem Pendukung Keputusan Pemilihan Guru Produktif Peserta Pelatihan Asesor Kompetensi Lsp P1 Smk Swasta Dwiwarna Medan Menggunakan Metode the Extended Promethee Ii (Exprom Ii). KOMIK (Konferensi Nasional Teknologi Informasi Dan Komputer), 2(1). https://doi.org/10.30865/komik.v2i1.922

Kementerian Pendidikan dan kebudayaan. (2016). Revitalisasi Pendidikan Vokasi. 10(September), 53.

Robbani, H., Megayanti, W. (2020). Formative Assessment Strategies Using Elearning. Intelektium 1 (1), 45-49.

Robbani, H., Rosadi, N., \& Nurfitria, O. (2020). Pembuatan Ruang Belajar Virtual di Pusat Kegiatan Belajar Masyarakat Smart Bangun Negeri. KANGMAS: Karya Ilmiah Pengabdian Masyarakat Volume 1 Nomor 1.

Masehat (2019) percepatan operasional LSP-P1 dibahas pada RNPK 2019, https://www.kemdikbud.go.id/main/blog/2019/02/percepatan-operasionalisasi-lspp1-dibahaspada-rnpk-2019

Hapsari, S. (2019). Metodologi Penelitian. Jakarta: Unindra Press 